\title{
Hubungan Pengetahuan dan Dukungan Keluarga dengan Perilaku Penyalahgunaan Napza di Kelas IIA Lembaga Pemasyarakatan Jambi
}

\author{
Nel Efni ${ }^{1}$ \\ Sekolah Tinggi Ilmu Kesehatan Baiturahim Jambi ${ }^{1}$ \\ nel_efni@yahoo.com
}

\begin{abstract}
The causes of drug abuse are complex due to the interaction of various factors, including individual factors such great curiosity to try and unknowingly or think long about the consequences later in life, environmental factors such as family problems or a broken home or social environment / community one even all members become abusers drug. This research is a quantitative research using Cross sectional design. The population in this study is the victim of drug abuse which amounted to 545 people and a total sample of 40 respondents using simple random sampling technique and the data were analyzed using univariate and bivariate by using the chi-square test. There is The relationship of knowledge and family support to the behavior of drug abuse in class IIA prison Jambi. Expected to be used as inputs in the preparation of the program increased knowledge about the dangers of drugs.
\end{abstract}

Keywords: behavioral abuse drugs, knowledge, family support.

\section{PENDAHULUAN}

NAPZA (Narkoba, Psikotropika, dan Zat adiktiif) termasuk golongan bahan atau zat yang jika masuk ke dalam tubuh akan mempengaruhi fungsi-fungsi yang dapat merusak tubuh terutama otak (BNN, 2011). Penyebab penyalahgunaan Napza sangatlah kompleks akibat interaksi bebagai faktor, diantaranya faktor individu seperti keingintahuan yang besar untuk mencoba dan tanpa sadar atau berfikir panjang tentang akibat kemudian hari, faktor lingkungan seperti keluarga bermasalah atau broken home atau lingkungan pergaulan/komunitas yang salah satu bahkan semua anggotanya menjadi penyalahgunaan, pengedar gelap narkoba dan faktor ketersediaan narkoba seperti narkoba yang semakin mudah didapatkan, harga narkoba yang semakin murah dan terjangkau. (BNN, 2011).

Selain itu pengetahuan sangat berpengaruh sekali, karena dengan ketidaktahuan dampak dan bahaya Napza itulah para korban tersebut menyalahgunakan napza. Dukungan keluarga sangat penentu utama dalam masalah ini, karena tanpa adanya dukungan keluarga dengan memberikan informasi kepada anak-anak bagaimana memilih pergaulan yang sehat dan bebas dari bahaya napza, anak-anak tentu akan bisa salah arah.

Menurut WHO,

1984 penyalahgunaan Napza adalah pemakaian Napza secara terus menerus atau sekalisekali secara berlebihan dan tidak menurut petunjuk dokter. Senada dengan Departemen Kesehatan (2001) menyatakan bahwa penyalahgunaan NAPZA adalah penggunaan NAPZA secara patologis (di luar tujuan pengobatan) yang sudah berlangsung selama paling sedikit satu bulan berturut-turut dan menimbulkan gangguan dalam fungsi sosial, sekolah, atau pekerjaan. Penyalahgunaan napza seperti fenomena gunung es yang muncul di atas permukaan laut, sementara di bawahnya yang terbesar tidak muncul. Sehingga upaya yang serius tidak hanya dalam pencegahan tetapi pemulihan mereka yang telah menjadi pecandu terkena yang meliputi pemulihan medis dan sosial. Dukungan keluarga dianggap mampu melemahkan dampak stres dan langsung 
dapat memperkuat kesehatan mental individu.

Berdasarkan penelitian BNN menunjukkan bahwa satu setengah persen populasi penduduk Indonesia berarti 3,2 terlibat penyalahgunaan narkoba, laki-laki $79 \%$ dan perempuan $21 \%$. (catatan: prosentase tersebut menunjukan para penyalahguna mengkonsumsi lebih dari satu jenis narkoba), selain itu 15 ribu orang tiap tahun meninggal karena narkoba. Keadaan ini sungguh memprihatinkan (BNN. 2011). Sementara penelitian dari Srikartini (2013), tentang hubungan religiusitas dan dukungan keluarga dengan resiliensi pada penggunaan NAPZA di LSM persaudaraan EXS korban Napza Kota Jambi bahwa, dari 65 responden, sebanyak 17 responden $(26,2 \%)$ memiliki dukungan keluarga yang kurang baik. Sebanyak 48 responden $(73,8 \%)$ memiliki dukungan keluarga yang baik. Hasil uji statistic diperoleh nilai $\mathrm{p}$-value $=0,025$ $(\mathrm{p}<0,05)$, berarti ada hubungan bermakna antara dukungan keluarga dengan resiliensi pada penggunaan Napza. Dukungan keluarga yang baik akan mengakibatkan kemampuan resiliensi yang dimiliki oleh pengguna Napza juga akan tinggi.

Hasil survey awal yang dilakukan peneliti pada tanggal 24 September 2014 di kelas IIA Lembaga Pemasyarakatan Jambi dengan mewawancarai 10 orang tahanan. Dari 10 tahanan 2 orang merupakan pengedar dan pengguna, 5 mengatakan hanya coba-coba dan ingin tahu rasa dari menggunakan narkoba dan 3 tahanan lainya mengatakan bahwa orang tuanya kurang memperhatikan dirinya. Hasil tersebut didapatkan bahwa tingginya penggunaan Narkoba terutama disebabkan oleh pengetahuan yang kurang tentang bahaya narkoba tersebut dan faktor keluarga. Berdasarkan data dari Lembaga Pemasyarakatan Klas II Provinsi Jambi, jenis narkoba yang dikosumsi pelajar tahun ini bertambah, kalau dulu pelajar menggunakan ganja, kini sudah ke taraf pengguna sabu-sabu dan pil ekstasi.

\section{METODE PENELITIAN}

Penelitan ini merupakan penelitian kuantitatif dengan menggunakan desain penelitian Cross Sectional, yang bertujuan untuk mengetahui hubungan pengetahuan dan dukungan keluarga dengan perilaku penyalahgunaan Napza di Kelas IIA Lembaga Pemasyarakatan Propinsi Jambi. Populasi dalam penelitian ini adalah korban Penyalahgunaan Napza, dengan jumlah populasi sebanyak 545 responden. Teknik Pengambilan sampel dalam penelitian ini adalah simple random sampling dengan jumlah sample 40 orang. Data di peroleh dengan cara wawancara menggunakan kuesioner pengetahuan dan dukungan keluarga. Penelitian ini dilaksanakan pada tanggal 16 - 20 Maret 2015 di Kelas IIA Lembaga Pemasyarakatan Propinsi Jambi. Data di analisa secara univariat dan bivariat dengan menggunakan uji chi-square. Pengukuran variabel-variabelnya dilakukan hanya satu kali, dengan tujuan untuk mengetahui hubungan antara variabel independen (pengetahuan dan dukungan orang tua) dengan variabel dependen (perilaku penyalahgunaan NAPZA).

Instrumen penelitian yang digunakan dalam penelitian ini adalah lembaran kuesioner untuk mendapatkan data tentang hubungan pengetahuan dan dukungan keluarga dengan penyalahgunaan Napza di Kelas IIA Lembaga Pemasyarakatan Provinsi Jambi. Kueisioner penelitian ini berisikan pengetahuan, dukungan keluarga dan perilaku penyalahgunaan napza, data dikumpulkan melalui kuisioner dan dokumentasi yang berasal dari Lembaga Pemasyarakatan Kelas IIA Provinsi Jambi dan Badan Narkotika Nasional Provinsi Jambi. Kenudian diolah menggunakan komputer sebagai alat bantu dengan cara Editing, Coding, Scoring, Entry data, Cleaning data. Data di analisa secara univariat dan bivariat dengan menggunakan uji chi-square. 
HASIL DAN PEMBAHASAN

Karakteristik Responden

Karakteristik responden pada penelitian ini meliputi : jenis kelamin, umur dan pekerjaan.

Jenis Kelamin

Tabel 1. Jumlah Responden berdasarkan Jenis Kelamin di Kelas IIA Lembaga Pemasyarakatan Jambi.

\begin{tabular}{llcc}
\hline No & Jenis kelamin & Jml & $\begin{array}{c}\text { Persentase } \\
(\boldsymbol{\%})\end{array}$ \\
\hline 1. & Pria & 40 & 100 \\
2. & wanita & - & - \\
& Jumlah & 40 & 100 \\
\hline
\end{tabular}

Berdasarkan Tabel 1 dengan jumlah responden sebanyak 40 orang, semua narapidana yang dijadikan responden adalah berjenis kelamin laki-laki yaitu 40 orang (100\%).

\section{Umur/Usia}

Tabel 2. Jumlah Responden berdasarkan Umur di Lembaga Pemasayarakatan Klas IIA Jambi.

\begin{tabular}{cccc}
\hline No. & Umur & Jml & $\begin{array}{c}\text { Persentase } \\
(\%)\end{array}$ \\
\hline 1. & $15-19$ thn & 1 & 2,5 \\
2. & $20-25$ thn & 14 & 35 \\
3. & $26-30$ thn & 18 & 45 \\
4. & $31-35$ thn & 5 & 12,5 \\
5. & $>35$ thn & 2 & 5 \\
& Jumlah & 40 & 100 \\
\hline
\end{tabular}

Berdasarkan Tabel 2 dengan jumlah responden sebanyak 40 orang, jumlah terbanyak adalah usia 26-30 tahun (45\%).

\section{Pendidikan}

Tabel 3. Jumlah Responden berdasarkan Pendidikan di Lembaga Pemasyarakatan Klas IIA Jambi.

\begin{tabular}{|c|c|c|c|}
\hline No & Pendidikan & Jml & $\begin{array}{c}\text { Persentase } \\
(\%)\end{array}$ \\
\hline 1. & SD/sederajat & 9 & 22,5 \\
\hline 2. & SMP/sederajat & 23 & 57,5 \\
\hline 3. & SMA/sederajat & 8 & 20 \\
\hline \multirow[t]{2}{*}{4.} & Perg Tinggi & . & \\
\hline & Jumlah & 40 & 100 \\
\hline
\end{tabular}

Berdasarkan Tabel 3 diketahui bahwa responden dengan pendidikan SMP/sederajat lebih banyak $(57,5 \%)$.

\section{Analisa Univariat}

Gambaran pengetahuan

Tabel 4. Distribusi Frekuensi Responden Berdasarkan Pengetahuan di Kelas IIALembaga Pemasyarakatan Jambi

\begin{tabular}{llcc}
\hline No & Pengetahuan & Frekuensi & $\begin{array}{c}\text { Persentase } \\
(\%)\end{array}$ \\
\hline 1. & Baik & 16 & 40 \\
2. & Kurang Baik & 24 & 60 \\
& Jumlah & 40 & 100 \\
\hline
\end{tabular}

Berdasarkan tabel 4 Hasil penelitian menunjukan dari 40 pengguna napza diketahui bahwa pengguna napza dengan pengetahuan kurang baik, lebih banyak yaitu 24 orang $(60 \%)$.

\section{Gambaran dukungan keluarga}

Tabel 5. Distribusi Frekuensi Responden Berdasarkan Dukungan Keluarga di Kelas IIA Lembaga Pemasyarakatan Jambi

No. Dukungan Frekuensi Persentese

\begin{tabular}{llcc} 
& & $(\boldsymbol{\%})$ \\
\hline 1. & Baik & 18 & 45 \\
& Kurang & 22 & 55 \\
& $\begin{array}{l}\text { baik } \\
\text { Jumlah }\end{array}$ & 40 & 100 \\
\hline
\end{tabular}

Berdasarkan 5 Hasil penelitian menunjukan dari 40 pengguna napza, tersebut diketahui bahwa pengguna napza dengan dukungan kurang baik, lebih banyak yaitu $22(55 \%)$.

\section{Gambaran Perilaku penyalahgunaan Napza}

Tabel 6. Distribusi Frekuensi Responden Berdasarkan Perilaku Penyalahgunaan Napza di Kelas IIA Lembaga Pemasyarakatan Jambi

\begin{tabular}{cccc}
\hline No & $\begin{array}{c}\text { Prilaku } \\
\text { Penyalahgunaan } \\
\text { Napza }\end{array}$ & Frekuensi & $\begin{array}{c}\text { Persentase } \\
(\%)\end{array}$ \\
\hline 1. & Beresiko Rendah & 19 & 47,5 \\
2. & Beresiko Tinggi & 21 & 52,5
\end{tabular}

Hubungan Pengetahuan dan Dukungan Keluarga dengan Perilaku Penyalahgunaan Napza di Kelas IIA Lembaga Pemasyarakatan Jambi 
Jumlah

40

100

Berdasarkan tabel 6 hasil penelitian menunjukkan dari 40 pengguna napza diketahui bahwa penyalahgunaan napza beresiko tinggi lebih banyak yaitu 21 orang $(52,5 \%)$.

Analisa Bivariat

Hubungan Pengetahuan dengan

Periklaku Penyalagunaan Napza DI

Kelas IIA Lembaga Pemasyarakatan Jambi

Tabel 7. Distribusi Frekuensi Hubungan Pengetahuan dengan Perilaku Penyalahgunaan Napza di Lembaga Pemasyarakatan Klas IIA Jambi

\begin{tabular}{cccccccc}
\hline \multirow{2}{*}{ Pengetahuan } & \multicolumn{3}{c}{ Perilaku Penyalahgunaan Napza } & Frekuensi & P-Value \\
& \multicolumn{2}{c}{ Resiko Rendah } & \multicolumn{2}{c}{ Resiko Tinggi } & & & \\
\cline { 2 - 5 } Baik & Jml & $\%$ & Jml & $\%$ & Jml & $\%$ & \\
Krg Baik & 12 & 75 & 4 & 25 & 16 & 100 & \\
Jml & 7 & 29,2 & 17 & 70,8 & 24 & 100 & 0,012 \\
\hline
\end{tabular}

Berdasarkan Tabel 7 Hasil penelitian menunjukan bahwa dari 40 pengguna Napza, dari 16 pengguna yang memiliki pengetahuan baik, 12 orang (75\%) memiliki perilaku penyalahgunaan napza beresiko rendah dan 4 pengguna $(25 \%)$ dengan perilaku penyalahgunaan napza beresiko tinggi. Dari 24 pengguna napza yang memiliki pengetahuan kurang baik, 7 orang $(29,2 \%)$ dengan perilaku penyalahgunaan napza beresiko rendah dan 17 (70,8\%) memiliki perilaku penyalahgunaan napza beresiko tinggi.

Dari uji analisis statistik dengan tingkat kepercayaan 95\% dengan nilai kemaknaan $5 \%(\alpha=0,05)$, diperoleh $p$-value $(0,012)<$ alpha $(0,05)$. Hal ini menunjukkan ada hubungan yang bermakna antara pengetahuan dengan perilaku penyalahgunaan napza.

Hasil penelitian ini sejalan dengan hasil penelitian sebelumnya yang dilakukan oleh Prisaria (2012), dengan judul hubungan pengetahuan dan lingkungan sosial terhadap tindakan pencegahan penyalahgunaan napza pada siswa sma negeri 1 jepara yang menyatakan ada hubungan positif antara pengetahuan siswa SMA tentang NAPZA terhadap tindakan pencegahan penyalahgunaan NAPZA.

Hasil penelitian menunjukkan bahwa sebagian besar responden yang pengetahuannya kurang baik, perilaku penyalahgunaan napza juga beresiko tinggi. Kurangnya pengetahuan kemungkinan disebabkan oleh kurangnya informasi yang didapatkan tentang napza dan dampak buruk yang dapat ditimbulkan oleh napza serta rendahnya tingkat pendidikan responden. Menurut Prisaria (2012), yang menyatakan bahwa semakin tinggi pengetahuan maka semakin tinggi pula pencegahan terhadap penyalahgunaan Napza.

Hasil penelitian membuktikan teori potter dan perry (2005), yang menyatakan bahwa salah satu hal yang mempengaruhi pengetahuan seseorang adalah latar belakang pendidikan. Latar belakang pendidikan seseorang akan menentukan cara seseorang utnuk mengerti dengan masalah yang sedang dihadapi. hasil penelitian diketahui bahwa tingkat pendidikan reponden adalah $\mathrm{SD} /$ sederajat dan SMP/sederajat lebih tinggi sehingga berpengaruh pada pengetahuan yang rendah pada responden tentang napza dan dampak yang ditimbulkannya.

Pengetahuan merupakan hasil dari tahu dan ini terjadi setelah orang melakukan penginderaan terhadap suatu objek tertentu. Dari pengalaman dan penelitian terbukti bahwa perilaku yang didasari oleh pengetahuan akan lebih 
langgeng daripada perilaku yang tidak didasari oleh pengetahuan (Notoatmodjo, 2010).

Hasil penelitian ini sesuai dengan pendapat Notoatmodjo (2007), yang mengatakan bahwa pengetahuan atau kognitif merupakan domain yang sangat penting untuk terbentuknya perilaku seseorang. Hal ini sejalan dengan hasil penelitian dari Nurmalis (2011), yang mengatakan menyatakan bahwa ada pengaruh penyuluhan napza terhadap pengetahuan dan sikap remaja dengan $p$ value $=0.000$.
Disarankan untuk meningkatkan pengetahuan masyarakat maka perlu pemberian informasi dan penyuluhan untuk mencegah terjadinya penyalahgunaan napza, terutama untuk usia-usia produktif karena dari hasil penelitian, pengguna napza terbanyak adalah pada usia 26-30 tahun. Pemberian informasi dapat melalui media elektronik, leaflet, memperbanyak poster dan sebagainya tentang bahaya napza.

\section{Hubungan Dukungan Keluarga dengan Perilaku Penyalahgunaan Napza di Kelas IIA Lembaga Pemasyarakatan Jambi}

Tabel. 8. Disribusu Frekuensi Hubungan Dukungan Keluarga dengan Perilaku Penyalahgunaan Napza di Kelas IIA Lembaga Pemasyarakatan Jambi.

\begin{tabular}{|c|c|c|c|c|c|c|c|}
\hline \multirow{2}{*}{$\begin{array}{l}\text { Dukungan } \\
\text { Keluarga }\end{array}$} & \multicolumn{4}{|c|}{$\begin{array}{l}\text { Perilaku Penyalahgunaan Napza } \\
\text { resiko Rendah Resiko Tinggi }\end{array}$} & \multicolumn{2}{|c|}{ Frekuensi } & \multirow[t]{2}{*}{ P-Value } \\
\hline & $\mathrm{Jml}$ & $\%$ & $\mathrm{Jml}$ & $\%$ & $\mathrm{Jml}$ & $\%$ & \\
\hline Baik & 14 & 77,8 & 4 & 22.2 & 18 & 45 & \multirow{3}{*}{0,002} \\
\hline Kurang Baik & 5 & 22,7 & 17 & 77.3 & 22 & 55 & \\
\hline Jml & 19 & 47,5 & 21 & 52,5 & 40 & 100 & \\
\hline
\end{tabular}

Berdasarkan tabel 8 Hasil penelitian menunjukan bahwa dari 40 pengguna napza, 18 pengguna dengan dukungan keluarga yang baik, 14 orang $(77,8 \%)$ memiliki perilaku penggunaan napza beresiko rendah dan 4 orang $(22,2 \%)$ dengan perilaku penggunaan napza beresiko tinggi. Dari 22 pengguna yang memiliki dukungan keluarga kurang baik, 5 orang $(22,7 \%)$ memiliki perilaku penggunaan napza beresiko rendah dan 17 orang $(77,3 \%) \quad$ dengan perilaku penggunaan napza beresiko tinggi. Hasil uji analisis statistik chi-square dengan tingkat kepercayaan $95 \%$ dengan nilai kemaknaan $5 \%(\alpha=0,05)$ diperoleh $p$-value $(0,002)<$ alpha $(0,05)$, Hal ini menunjukkan ada hubungan yang bermakna antara dukungan keluarga dengan perilaku penggunaan napza. Hasil penelitian menunjukan bahwa sebagian besar responden yang dukungan keluarga baik, penyalahgunaan napza beresiko rendah, namun ada responden yang mendapatkan dukungan keluarga baik beresiko tinggi untuk kembali melakukan penyalahgunaan napza. Resiko tinggi tersebut kemungkinan disebabkan oleh kurangnya dukungan informasi dari keluarga sehingga responden beresiko tinggi untuk kembalimelakukan penyalahgunaan napza.

Menurut Friedman (2008) dukungan keluarga adalah sikap, tindakan dan penerimaan keluarga, anggota keluarga memandang bahwa orang yang bersifat mendukung selalu siap memberikan dukungan dan bantuan jika diperlukan, dukungan sosial keluarga adalah sebuah proses yang terjadi sepanjang nasa kehidupan, sifat dan jenis dukungan sosial berbeda-beda dalam berbagai tahap-tahap siklus kehidupan, dukungan sosial keluarga membuat keluarga mampu berfungsi dengan berbagai kepandaian dan akal, sebagai akibat, hal ini meningkatkan kesehatan dan adaptasi keluarga. Potter \& Perry (2005), mengatakan bahwa dukungan keluarga sangat penting dalam menciptakan 
dan mempertahankan konsep diri anggotanya. Keluarga merupakan lingkungan pertama yang dikenal oleh individu dalam proses sosialisasinya, dukungan keluaraga merupakan bantuan yang dapat diberikan berupa barang, jasa, informasi dan nasehat yang dapat membuat individu merasa tentram disayang dan dihargai.

Sangat diperlukan dukungan keluarga yang baik yaitu berupa dorongan, motivasi, empati, ataupun bantuan yang dapat membuat individu pengguna napza merasa lebih tenang dan aman, sehingga pada saat kembali ketengah-tengah keluarga individu tersebut tidak terjerumus dan kembali menggunakan napza. Dukungan tersebut bisa diberikan oleh orang tua, suami, istri, anak ataupun keluarga dekat lainnya, karena dukungan dari keluarga dekat akan mendatangkan rasa senang, rasa aman, nyaman dan membuat individu pengguna napza merasa mendapat dukungan emosional yang dapat mempengaruhi ketenangan jiwanya. Dukungan keluarga berkaitan dengan pembentukan keseimbangan mental dan kepuasan psikologis. Jadi semakin tinggi dukungan keluarga pada diri seseorang maka semakin baik pula orang tersebut dalam menangani masalah yang sedang dihadapinya.

\section{SIMPULAN}

Berdasarkan hasil penelitian maka disimpulkan:

1. Dari 40 pengguna napza diketahui bahwa 21 responden $(52,5 \%)$ dengan perilaku penyalahgunaan napza beresiko tinggi.

2. Dari 40 pengguna napza, diketahui bahwa $24(60 \%)$ responden dengan pengetahuan kurang baik.

3. Dari 40 pengguna, diketahui bahwa 22 responden $(55 \%)$ dengan dukungan keluarga kurang baik.

4. Ada hubungan pengetahuan dengan perilaku penyalahgunaan napza di Kelas IIA Lembaga Permasyarakatan Jambi
5. Ada hubungan dukungan keluarga dengan perilaku penyalahgunaan napza di Kelas IIA Lembaga Permasyarakatan Jambi.

\section{DAFTAR PUSTAKA}

Arikunto, S. 2006. Manajemen Penelitian. Rineka Cipta. Jakarta

BNN. 2005. "Penyalahgunaan Narkoba". Http://www.BNN.co.id. Diakses tanggal :12 Juni 2010

BNN. 2011. "Advokasi Pencegahan Penyalahgunaan Narkoba". Jakarta

BNN.2013. "BNNP Jambi Lakukan Sosialisasi Inpres No 12 Tahun 2011 ".

http://kerinci.kemenag.go.id/2013/05/ 30/bnnp-jambi-lakukan-sosialisasiinpres-no-12-tahun-2011/ : Diakses tanggal 26 januari 2014

BNN. 2013. Jumlah Pengguna Narkoba. Jambi

Dadang, 2006. Penyalahgunaan dan Ketergantungan NAPZA Edisi Kedua, Universitas Kedokteran Universitas Indonesia. Jakarta.

Drs. Mohammad Yamin Sumitra: Penanganan Narkoba Harus Maksimal

.Http://Bnnpjambi.Blogspot.Com/201 3/06/Penanganan-Narkoba-HarusMaksimal.Html

Effendy, N. 1998. Dasar-Dasar Keperawatan EGC.Jakarta.

Friedman. 2008. Keperawatan Keluarga, Teori dan Praktik. Edisi 3. Raja wana. Jakarta

Hidayat, A.A. 2007. Riset Keperawatandan Teknik Penulisan Ilmiah. Salemba Medika. Jakarta.

Notoadmodjo, S. 2003. Metodologi Penelitian Kesehatan. Rineka Cipta : Jakarta.

$\begin{array}{ccc} & 2005, & \text { Metodologi } \\ \text { Penelitian } & \text { Kesehatan. } & \text { EdisiRevisi. } \\ \text { Rineka Cipta. Jakarta. } & \end{array}$


2007. Promosi Kesehatan

Teoridan Praktik. Rineka Cipta. Jakarta

2010. Ilmu Prilaku

Kesehatan. Rineka Cipta. Jakarta

Nurmalis. 2011. Pengaruh Penyuluhan Terhadap Pengetahuan dan Persepsi Remaja di SMK IX Lurah Kota Jambi 2011. Skripsi Stikes Baiturrahim. Jambi

Noraliyah. 2004. Pengaruh Perhatian Orang Tua dan Kedisiplinan Belajar Terhadap Prestasi Belajar Anak di MI NU Banat Kudus Kelas III-V Tahun Ajaran 2003/2004. http://library.walisongo.ac.id/digilib/f iles/disk1/13/jtptiain-gdl-s1-2004noraliyah3-626-BAB2 310-5.pdf

Potter \& Perry. 2005. Buku Ajar Fundamental Keperawatan. Edisi 4. Volume 1. EGC. Jakarta

Prisaria, N. 2012. Hubungan Pengetahuandan Lingkungan Sosial Terhadap Tindakan Pencegahan Penyalahgunaan Napza Pada Siswa SMA Negeri 1 Jepara. Skripsi Universitas Diponegoro. Semarang

Purwati, A., Hubungan antara dukungan sosial dengan depresi pada remaja penyalahgunaan Napza, Jurnal Ilmu Keperawatan Vol.01/no.01, Hal 14.2006

Sarafino. (dalam Potter \& Perry, 2005), Buku Ajaran Fundamental Keperawatan. Edidi 4. Volume 1. EGC. Jakarta

Saputro 2011, dalam http://digilib.unimus.ac.id/files/disk1/ 132/jtptunimus-gdl-mujusitisa-65952-babi.pdf

Srikartini. 2013., Hubungan Dukungan Keluarga Dengan Resiliensi Pada Penggunaan Napza di LSM persaudaraan EXS Korban Napza Kota Jambi. Skripsi.Stikes Baiturrahim. Jambi.

Sri Wahyuni. 2013. Hubungan Pengetahuan dan Prilaku dengan
Riwayat Pemakaian Napza.

Skripsi.Stikes Baiturrahim. Jambi Stikba. 2013. Buku Panduan Skripsi. Jambi Sunaryo. 2004. Psikologi untuk Keperawatan. EGC. Jakarta

UU RI No.5 /1997.Tentang Narkotika dan Penyalahgunaan.

Wordpress, 2009. Negara-negara Pemasokdan Pemakai Narkotika Terbesar di Dunia. Http://www.Narkotika.co.id. Diakses tanggal 12 Juni 2014

Yonathan, N. 2013. Mahir Menggunakan SPSS Secara Otodidak. PT Gramedia. Jakarta 